\title{
MODEL PEMBELAJARAN TERPADU (STUDI KASUS DI YAYASAN MUHAMMAD YA'QUB JOMBANG)
}

\author{
Siti Hesniyatul Jamila \\ STIT Aqidah Usymuni Sumenep \\ Email: hesniyatuljamila@gmail.com
}

\begin{abstract}
ABSTRAK
Penelitian ini bertujuan mendeskripsikan implementasi model pembelajaran terpadu di lembaga pendidikan yang berada di bawah naungan yayasan Muhammad Ya'qub Jombang, yang meliputi dilihat dari faktor tujuan, pendidik, peserta didik, strategi pembelajaran, materi, sarana prasarana dan evaluasi model pembelajaran terpadu di lembaga pendidikan yang berada di bawah naungan yayasan Muhammad Ya'qub Jombang. Tujuan pembelajaran ini yaitu terwujudnya Visi Misi yang sudah terintegrasi dengan tujuan Pendidikan Nasional dan nilai pendidikan yang terkandung dalam QS. Al-Baqarah ayat 39 dan 132. Dilihat dari faktor pendidik, masih terdapat perbedaan kualitas dalam mengkolaborasi dan mengintegrasikan pembelajaran. Dilihat dari faktor peserta didik, sudah memahami pentingnya pembelajaran. Dilihat dari faktor sarana prasarana, yaitu Buku Detik-Detik Ujian Nasional dan buku saku Biologi, media pembelajaran DVD Harun Yahya dan buku Sains (SD/MI) 2 in 1. Dilihat dari faktor strategi pembelajaran yaitu kolaborasi dan integrasi, kolaborasi yang dimaksudkan yaitu dengan mengamalkan nilai pendidikan yang terkandung dalam Q.S Al-'Alaq: 1 dan mengintegrasikan dengan nilai agama yang terintegrasi dengan pembahasan. Dilihat dari faktor materi, dibagi dua kelompok besar yaitu ketuhanan dan kemanusiaan. Dilihat dari faktor sistem evaluasi/penilaian: Suksesnya pembelajaran dilihat pada suksesnya domain kognitif, afektif dan Psikomotorik, juga pengayaan bagi peserta didik spesial dan remedial bagi peserta didik di bawah standar. Saran: Implementasi model pembelajaran terpadu di lembaga pendidikan yang berada di bawah naungan yayasan Muhammad Ya'qub Jombang untuk sementara sudah banyak mengandung nilai positif. Oleh karena itu, ada baiknya lebih disempurnakan dan dijadikan pertimbangan untuk diimplementasikan melalui kebijakan secara nasional.
\end{abstract}

\section{Kata kunci : Model Pembelajaran, Metode Pembelajaran, Evaluasi Pembelajaran}

\section{ABSTRACT}

This study aims to describe the implementation of integrated learning models in educational institusions that are under the auspices of the foundation of Muhammad Ya'qub Jombang. The implementation of an integrated learning models on Biology subjects is called the shared models (divided model). However, the integrated learning models in educational institusions under the auspices of the foundation of Muhammad Ya'qub Jombang is superior because there is also educational training in learning. The purpose of this learning is the realization of the vision mission that has been integrated with the objectives of national education and the value of education contained in QS. Al-Baqarah verses 39 and 132. Judging from the factors of educators, there are feel still differences in quality in collaborating and integrating learning. Judging from the factors of student, they have understood the importance of learning. Viewed from the infrastructure facilities, namely the national examination secondary book and Biology pocket book, the Harun Yahya DVD learning media and the 2 in 1 Science (SD/MI) book. Judging from the factors of strategy factor of collaboration and integration, the intended collaboration is by practice the value of education contained in QS. Al-'Alaq : 1 and integrate with religious values integrated with the discussion. Judging from the material factors, divided into to major groups, namely divinity and humanity. Judging from the evaluation/ assessment system factors: success in learning is seen in the success of the cognitive, affective, and psychomotor domains, as well as substandard enrichment for special and remedial students for students. Suggestion: Implementation of integrated learning model in educational institusions under the auspices of the foundation of Muhammad Ya'ub Jombang for a while has a lot of positive values. Therefore, it is better to be refined and taken in consideration to be implemented through policy nationally.

\section{Keyword : Model of learning, learning method, Evaluasion of learning}


Siti Hesniyatul Jamila

\section{Pendahuluan}

Model pembelajaran terpadu merupakan salah satu model implementasi kurikulum yang dianjurkan untuk diaplikasikan terutama jenjang pendidikan dasar, mulai dari tingkat SD/MI maupun SMP/MTs, tetapi tidak menutup kemungkinan untuk dikembangkan pada tingkat pendidikan menengah (SMA/SMK). $\mathrm{Hal}$ ini bergantung pada kecenderungan materi-materi yang memiliki potensi untuk dipadukan dalam satu tema tertentu. Manusia yang mulia di sisi Tuhan adalah manusia yang selalu berusaha mempersatukan ilmu, iman dan amal dalam hidupnya. Hal ini sebagaimana nilai pendidikan yang terkandung dalam surat $\mathrm{Al}$ Mujadilah ayat 11 bahwa hakikat manusia tidak bisa dipisahkan dari kemampuan untuk mengembangkan ilmu pengetahuan, maka ilmu yang disertai iman adalah ukuran derajat manusia, sehingga manusia yang berkualitas adalah manusia yang mencapai ketinggian ilmu, iman dan amal.

Adapun berdasarkan Undang-Undang Republik Indonesia tentang Sistem Pendidikan Nasional Nomor 20 Tahun 2003 pada $B A B$ II tentang Dasar, Fungsi dan Tujuan yang tertera pada Pasal 3 , Pendidikan Nasional berfungsi mengembangkan kemampuan dan membentuk watak serta peradaban bangsa yang bermartabat dalam rangka mencerdaskan kehidupan bangsa, bertujuan untuk berkembangnya potensi peserta didik agar menjadi manusia yang beriman dan bertakwa kepada Tuhan Yang Maha Esa, berakhlak mulia, sehat, berilmu, cakap, kreatif, mandiri, dan menjadi warga negara yang demokratis serta bertanggung jawab. Selain itu, UNESCO memberikan arahan bahwa secara global pendidikan harus mengarah untuk mengembangkan potensi individu-individu dengan berprinsip pada learning to know, learning to do, learning to be, dan learning to live together.

Tuhan telah mendorong manusia untuk mempelajari semua fenomena yang ada di langit, bumi, gunung, bintang, tanaman, bijibijian, hewan, pergantian siang dan malam, penciptaan manusia, terjadinya hujan dan lain-lain, serta mengambil pelajaran dari apa yang terjadi. Dengan memeriksa ini semua secara seksama, manusia akan mengenali keindahan artistik ciptaan Tuhan di dalam dunia sekitar mereka dan akan menemukan bahwa Tuhan-lah yang menciptakan alam raya ini. Sains menawarkan metoda yang dengannya alam raya dan yang berada di dalamnya dapat diperiksa dengan teliti untuk menemukan keindahan ciptaan Tuhan dan sekaligus keajaibannya. Islam yang sebagian misinya sama dengan hal tersebut, karenanya tidak saja menerima Sains tetapi juga bahkan ikut memperkaya Sains, kemudian mengadopsinya sebagai alat untuk mempelajari ciptaan-Nya (Atmaja, 2011: 1).

Tidak sama dengan semua agama lainnya, Islam mengizinkan riset yang sifatnya "konklusif' yaitu dapat disimpulkan. Alasannya adalah bahwa Islam dapat memberikan jawaban yang akurat dan terukur tentang bagaimana kehidupan dan alam raya ini terbentuk. Jika diawali dengan dasar yang benar, riset ilmiah akan mengungkapkan kebenaran tentang asal muasal alam semesta dan seluruh kehidupan yang ada. Seperti yang dinyatakan oleh Einstein, salah seorang saintis terbesar abad 20, "Sains tanpa agama adalah pincang" yang berarti bahwa Sains tanpa petunjuk dari prinsip-prinsip agama tidak akan berlanjut secara benar dan membuang-buang waktu, dan bahkan lebih buruk lagi, sering-sering tidak "konklusif".

Islam adalah agama atas dasar alasan dan hati nurani. Seorang muslim mengenali kebenaran yang diturunkan oleh Allah SWT melalui kebijakan dan ilmunya, tetapi bukan kesimpulan tentang kebenaran yang ada dari hati nuraninya. Seseorang yang menggunakan alasan/ilmu dan nuraninya di dalam memeriksa fenomena apa saja dalam alam walaupun dia bukan salah satu seorang yang ahli dalam bidang tersebut akan mengerti bahwa fenomena itu diciptakan oleh Pemilik Kebijakan dan IImu.

74 Autentik: Jurnal Pengembangan Pendidikan Dasar, Vol.3, No.2, Juli 2019 
Walaupun hanya sedikit saja yang ia temukan dari ribuan faktor yang mempengaruhi fenomena itu, tetapi posisi itu telah cukup baginya untuk memahami bahwa fenomena itu diciptakan oleh Tuhan. Oleh karena itu, seseorang yang memanfaatkan alasan/ilmu dan nuraninya akan secara cepat mengerti kesesatan pernyataan bahwa alam semesta ini datang dan tercipta dengan sendirinya tanpa peran Tuhan. Ringkasnya, dengan cara yang komplit (ilmu dan nurani) seseorang akan dapat mengenali secara penuh kehadiran dan kemudian kebesaran Tuhan. Ayat yang menerangkan sifat orang-orang seperti itu terdapat dalam QS. Ali Imron : 191.

Yayasan Muhammad Ya'qub merupakan yayasan yang menaungi beberapa lembaga pendidikan formal dan non formal, meliputi RA, PAUD, TK dan SMA Primaganda, dan MI, MTs, MA, STIT dan pondok Al-Urwatul Wutsqo. Adapun pada hal ini hanya membahas pembelajaran terpadu mata pelajaran Biologi di MTs, MA dan STITAI-Urwatul Wutsqo Jombang serta SMA Primaganda Jombang. Visi lembaga pendidikan yang berada di bawah naungan Muhammad Ya'qub adalah terwujudnya masyarakat berkepribadian Mulia, paham al-Qur'an dan pengagung Tuhan Maha Pencipta melalui pendidik yang pejuang.

Karakteristik pengembangan kurikulum yang berada di lembaga pendidikan MTs, MA, dan SMA yang berada di bawah naungan yayasan Muhammad Ya'qub Jombang ini adalah jika diibaratkan dibagi dalam dua sayap, yaitu sayap kanan adalah al-Qur'an yang merupakan rajanya ilmu (pembelajarannya mulai dari hafalan, bacatulis al-Qur'an, terjemah perkata, analisa shorof dan nahwu terhadap ayat-ayat alQur'an, baca kitab, keguruan al-Qur'an, dan belajar cara mengamalkan atau nilai pendidikan al-Qur'an). Adapun sayap kiri adalah mata pelajaran yang diujikan secara nasional dengan strategi mengintegrasikan pembelajaran umum dengan IMTAQ. Jadi, hanya mata pelajaran bahasa Indonesia, matematika, bahasa Inggris dan mata pelajaran peminatan untuk SMA atau sederajat, tidak memasukkan mata pelajaran seperti Sejarah, PKN dan sebagainya, Hal ini juga berlaku di MTs AlUrwatul Wutsqo. Pengembangan kurikulum ini juga diimplementasikan di STIT AIUrwatul Wutsqo yang merupakan perguruan tinggi dengan dua jurusan yaitu PAI dan MPI (Manajemen pendidikan Islam) dengan dua mata kuliah yang menjadi karakteristik lembaga yaitu keguruan al-Qur'an (mulai dari hafalan, terjemah, analisa shorof nahwu di al-Qur'an, baca kitab, keguruan al-Qur'an, dan belajar cara mengamalkan al-Qur'an) dan pembelajaran Ipteks berbasis Imtaq (matematika, bahasa Indonesia dan Sains). Berdasarkan keunikan pengembangan kurikulum tersebut, maka penulis ingin mengetahui secara lebih mendalam tujuan dan strategi dari implementasi pengembangan kurikulum tersebut.

Adapun penelitian terdahulu yang berkenaan dengan ini pernah dilakukan oleh Prof. Dr. H.Syaifuddin Sabda M.Ag, dengan judul: Model Pelajaran Terintegrasi Mata Pelajaran Umum dengan Imtaq (Pengembangan Model Untuk Madrasah Aliyah) yang dilakukan pada tanggal 04 September 2010, dengan temuan penelitian bahwa Kurikulum MA yang ada sekarang pada dasarnya masih didesain secara sparated subject. Dalam hal ini mata pelajaran umum dan agama masing-masing berdiri sendiri, tidak dirancang secara terpadu antara Ipteks dan Imtaq. upaya pengintegrasian dapat dinyatakan masih sangat temporal, tidak terkonsepsikan dengan baik serta belum terlaksananya pengembangan dan implementasi kurikulum yang memadukan materi pelajaran umum dan agama tersebut.

Penelitian terdahulu kedua yaitu penelitian tahun 2012 yang berjudul "Perangkat Pembelajaran IPA terpadu bervisi SETS berbasis edutaiment pada tema pencernaan" oleh Sri Muliani Endang Susilawati et all. Hasil penelitiannya yaitu pembelajaran IPA di SMP 1 Kudus, SMP 4 Kudus, dan SMP 2 Undaan masih dibelajarkan secara konseptual, kurang dikaitkan dengan kehidupan sehari-hari, 
Siti Hesniyatul Jamila

konsep IPA masih dibelajarkan secara terpisah-pisah, dan suasana pembelajaran kurang mendukung pemahaman konsep mendorong perlunya dikembangkan perangkat pembelajaran IPA Terpadu bervisi SETS berbasis edutainment. Perangkat yang dikembangkan meliputi Silabus, RPP, buku ajar, slide presentasi, monopoli SETS, petunjuk praktikum, puzzle SETS, dan soal evaluasi. Adapun perbedaan hasil penelitian kali ini dengan sebelumnya adalah di pengembangan kurikulum dan strategi dalam mengimplemetasikannya di yayasan Muhammad Ya'qub Jombang. Berdasarkan hal-hal tersebut diatas, maka penulis memberi Judul karya ini yaitu "Model Pembelajaran Terpadu (Studi Kasus di Yayasan Muhammad Ya'qub Jombang).

\section{Metode Penelitian}

Penelitian ini menggunakan pendekatan kualitatif. Penulis sangat memegang peranan penting karena penulis merupakan instrumen kunci. Sumber data penelitian ini adalah informan. Informan penelitian ini adalah dewan pembina, ketua yayasan, kepala sekolah, bagian kurikulum, pendidik, peserta didik, dan observasi serta dokumentasi. Teknik pengumpulan data yaitu pengamatan, wawancara, dokumentasi dengan teknik analisis deskriptif. Adapun langkah-langkah yang dilakukan dalam analisis data adalah reduksi data, penyajian data, klasifikasi data, interpretasi data, dan verifikasi data. Keabsahan data dalam penelitian ini ditentukan dengan menggunakan kriteria kredibilitas (derajat kepercayaan). Dalam menguji keabsahan data penelitian ini, peneliti menggunakan beberapa metode, diantaranya: Perpanjangan keikutsertaan, triangulasi, baik triangulasi subyek (para informan) dan triangulasi metode yaitu wawancara, dokumentasi, observasi dan ketekunan dalam pengamatan.

\section{PEMBAHASAN}

Model pembelajaran terpadu merupakan salah satu model implementasi kurikulum yang dianjurkan untuk diaplikasikan terutama jenjang pendidikan dasar, mulai dari tingkat SD/MI maupun SMP/MTs, tetapi tidak menutup kemungkinan untuk dikembangkan pada tingkat pendidikan menengah (SMA/SMK). $\mathrm{Hal}$ ini bergantung pada kecenderungan materi-materi yang memiliki potensi untuk dipadukan dalam satu tema tertentu. Model pembelajaran terpadu ini diimplementasikan pada lembaga pendidikan yang berada di bawah naungan yayasan Muhammad Ya'qub, meliputi MTs, MA dan STIT Al-Urwatul Wutsqo serta SMA Primaganda.

Karakteristik pengembangan kurikulum yang berada di lembaga pendidikan MTs, MA, dan SMA yang berada di bawah naungan yayasan Muhammad Ya'qub Jombang adalah jika diibaratkan dibagi dalam dua sayap, yaitu sayap kanan adalah al-Qur'an yang merupakan rajanya ilmu (mulai dari hafalan, terjemah, analisa shorof nahwu di al-Qur'an, baca kitab, keguruan al-Qur'an, dan belajar cara mengamalkan al-Qur'an) dan sayap kiri adalah pelajaran yang diujikan secara nasional dengan strategi mengintegrasikan pembelajaran umum dengan IMTAQ. Jadi, hanya mata pelajaran bahasa Indonesia, matematika, bahasa Inggris dan mata pelajaran peminatan untuk SMA atau sederajat, tidak memasukkan mata pelajaran seperti Sejarah, PKN dan sebagainya. Adapun buku yang digunakan adalah buku detikdetik UN sejak kelas satu, buku saku Biologi dan DVD pembelajaran yang berkaitan dengan mata pelajaran Biologi serta buku Biologi (SD/MI) 2 in 1. Berikut ini visi, misi dan tujuan lembaga pendidikan MTs dan MA Al-Urwatul Wutsqo dan SMA Primaganda Jombang, yaitu :

a. Visi :

1) Terwujudnya Masyarakat Berkepribadian Mulia.

2) Paham Al-Qur'an.

3) Pengagung Tuhan Maha Pencipta. 
4) Sukses UN

b. Misi :

1) Mendidik siswa beriman dan berakhlak mulia.

2) Mendidik siswa paham al-Qur'an dan mengamalkannya.

3) Mendidik siswa pengagung Tuhan Maha Pencipta.

4) Sukses UN.

c. Tujuan :

1) Terwujudnya peningkatan siswa yang beriman dan berakhlak mulia.

2) Terwujudnya peningkatan kemampuan memahami, mengamalkan al-Qur'an dalam kehidupan sehari-hari.

3) Terwujudnya manusia yang ikhlas beramal untuk Allah.

4) Terwujudnya peningkatan lulusan UN dari tahun ke tahun.

Adapun visi, misi, tujuan dan strategi STIT Al-Urwatul Wutsqo Jombang adalah :

Visi :

Terwujudnya Masyarakat Berkepribadian Mulia, Paham al-Qur'an dan pengagung Tuhan Maha Pencipta melalui Pendidik yang Pejuang.

Misi :

1. Menyediakan dosen-dosen yang memahami peran dan tugasnya, memiliki kompetensi pedagogik, kompetensi kepribadian, kompetensi sosial dan kompetensi profesional, serta berkualifikasi akademik.

2. Menyediakan tenaga pendidik yang profesional.

3. Mempersiapkan mahasiswa menjadi pendidik yang memiliki kompetensi kepribadian, (Berkepribadian Mulia dan Pengagung Tuhan Maha Pencipta), kompetensi profesional, (termasuk Paham AIQuran), kompetensi pedagogik dan kompetensi sosial (Mujahid), serta berkualifikasi akademik.

4. Melaksanakan Tri Dharma Perguruan Tinggi.

5. Mengusahakan sarana/prasarana yang memadai.

Tujuan:

1. Terwujudnya kesepahaman atas visi dan misi Sekolah Tinggi IImu Tarbiyah al-
Urwatul Wutsqo Jombang pada seluruh civitas akademika.

2. Meningkatkan kinerja sebagai lembaga tenaga pendidik agama Islam yang unggul dalam misi akademik dan dakwah yang berdasarkan nilai-nilai keislaman.

3. Menyiapkan peserta didik menjadi sarjana pendidikan Islam yang beriman, bertakwa dan berakhlak mulia, yang memiliki kemampuan akademik dan profesional di bidang pendidikan Islam menuju terwujudnya masyarakat adil dan makmur yang diridhoi Allah.

4. Mengembangkan dan menyebarluaskan ilmu pengetahuan agama Islam dalam rangka memajukan Islam serta meningkatkan umat manusia.

5. Menjalin, meningkatkan dan memelihara kerjasama yang saling menguntungkan dengan pihak pemerintah, swasta, dan lembaga pendidikan tinggi dalam mengembangkan Pendidikan Islam.

\section{Strategi:}

a. Menyusun kurikulum yang merupakan perpaduan antara pengembangan ilmu pengetahuan, teknologi dan seni (Ipteks), dengan nilai-nilai keimanan dan ketaqwaan (Imtaq).

b. Menanamkan prinsip-prinsip keikhlasan pada semua civitas akademika (pimpinan, dosen, karyawan, mahasiswa, dan alumni) dengan upaya memberi kemudahan-kemudahan di bidang administrasi, dan tidak ada biaya bukan penghalang mencari ilmu.

c. Menegakkan prinsip-prinsip keimanan dalam semua kegiatan baik intra maupun ekstra.

Menurut Fogarty (1991:4-5) menyatakan 10 model pembelajaran terpadu. Modelmodel itu adalah sebagai berikut:

1. Model Connected (model terhubung) merupakan model integrasi interbidang studi.

2. Model Webbed (model jaring laba-laba) ialah pembelajaran terpadu yang menggunakan pendekatan tematik.

3. Model Integrated (model integrasi) merupakan pembelajaran terpadu yang 
Siti Hesniyatul Jamila

menggunakan pendekatan antar bidang studi.

4. Model Nested (tersarang) merupakan pengintegrasian kurikulum di dalam satu bidang disiplin ilmu secara khusus meletakkan fokus pengintegrasian pada sejumlah keterampilan mengajar yang ingin dilatihkan oleh guru pada peserta didik dalam satu unit pembelajaran untuk ketercapaian materi pelajaran (content).

5. Model Sequenced (model terurut) merupakan model pemaduan topik-topik antar mata pelajaran yang berbeda secara paralel dengan cara mengajarkan materi pelajaran yang memiliki kesamaan materi dan keterkaitan antar keduanya.

6. Model Shared (model terbagi) merupakan bentuk pemaduan pembelajaran akibat adanya overlapping konsep atau ide pada dua mata pelajaran sehingga menuntun peserta didik untuk membuka wawasan dan cara berpikir yang luas dan mendalam melalui pemahaman terhadap konsep secara lintas disiplin ilmu, atau suatu model pembelajaran terpadu dimana pengembangan disiplin ilmu yang memayungi kurikulum silang.

7. Model Threaded (bergalur) merupakan pendekatan pembelajaran yang ditempuh dengan cara mengembangkan gagasan pokok yang merupakan benang merah (galur) yang berasal dari konsep yang terdapat dalam berbagai disiplin ilmu.

8. Model Immersed (model terbenam) dirancang untuk membantu peserta didik dalam menyaring dan memadukan berbagai pengalaman dan pengetahuan dihubungkan dengan medan pemakaiannya melalui pengintegrasian semua data dari setiap mata pelajaran dengan mengaitkan ide-ide melalui minatnya.

9. Model Networked (model jaringan) merupakan model pemaduan pembelajaran yang mengendalikan kemungkinan pengubahan konsep, bentuk pemecahan masalah, maupun bentuk keterampilan baru setelah peserta didik mengadakan studi lapangan dalam situasi, kondisi dan konteks yang berbeda-beda.

10. Model Fragmented merupakan pembelajaran yang dilaksanakan secara terpisah yaitu hanya terfokus pada satu disiplin mata pelajaran, misalnya, mata pelajaran Matematika, IPA, IPS, Bahasa, dan sebagainya yang diajarkan secara terpisah.

Menurut Wiyani, (2012: 130) sepuluh model pembelajaran terpadu ini dikelompokkan menjadi tiga tipe model meliputi :

a. Model pembelajaran terpadu dalam satu bidang studi (Model Fragmented, Connected dan Nested).

b. Model pembelajaran terpadu antar bidang studi (Model Squened, Shared, Webbed, Threaded, dan Integrated).

c. Model pembelajaran terpadu dalam faktor diri peserta didik (Model Immersed dan Networked).

Prinsip-Prinsip Model Pembelajaran Terpadu adalah sebagai berikut :

1) Berpusat pada potensi, perkembangan, kebutuhan dan kepentigan peserta didik dan lingkungannya.

2) Beragam dan terpadu.

3) Tanggap terhadap perkembangan ilmu pengetahuan, teknologi dan seni.

4) Relevan dengan kebutuhan kehidupan.

5) Menyeluruh dan berkesinambungan.

6) Belajar sepenjang hayat.

7) Seimbang antara kepentingan Nasional dan kepentingan daerah.

Model pembelajaran terpadu sebagai suatu proses mempunyai beberapa karakteristik atau ciri-ciri, yaitu: holistik, bermakna, otentik dan aktif. Hal ini sesuai dengan prinsip-prinsip kunci tarbiyah yaitu fitrah, unik, holistik, integratif yaitu pembelajaran efektif haruslah terpadu, mendidik anak secara spiritual, moral, intelektual, fisik, emosi dan sosial. Integrasi haruslah mencakup topik, integrasi waktu, tempat, dan budaya, integrasi dalam kurikulum, integrasi antara pengetahuan, kepercayaan, nilai-nilai dan aplikasinya dan 
aksi. Aspek-aspek integrasi ini lebih mempunyai potensi yang kuat untuk mencapai pembelajaran efektif (Zainuddin, 2010: 113-114).

Disamping itu, Model pembelajaran terpadu harus menggunakan tema yang relevan dan berkaitan. Tema yang dibahas disajikan dalam konteks Sains-lingkunganteknologi-masyarakat, yang melibatkan aktivitas peserta didik secara berkelompok maupun mandiri (Trianto, 2010: 9). Menurut Cohen dan Manion (1992) dan Brand (1991), terdapat tiga kemungkinan variasi pembelajaran terpadu yang berkenaan dengan pendidikan yang dilaksanakan dalam suasana pendidikan progresif yaitu kurikulum terpadu (integrated curriculum), hari terpadu (integrated day), dan pembelajaran terpadu (integrated learning).

Indonesia adalah sebuah negara besar yang mayoritas penduduknya memeluk agama Islam. Bangsa yang besar ini idealnya mampu menjadi kekuatan yang cukup berpengaruh dalam percaturan "dunia", baik dalam skala nasional maupun internasional. Namun jumlah penduduk muslim yang besar ini belum memiliki kekuatan sebagaimana seharusnya yang dimiliki. Sebab belum didukung oleh kualitas SDM yang memadai. Berbagai pihak telah berusaha merumuskan masalah dan jawabannya. Salah satu rekomendasi yang dihasilkan adalah segera mengupayakan peningkatan kualitas SDM, melalui peningkatan kualitas pendidikan.

Kehidupan manusia akan berlanjut sampai pada kehidupan akhirat. Kehidupan dunia adalah sebagai tempat untuk beriman, berakhlak dan beramal kebajikan, untuk mencari bekal hidup di akhirat. Ibarat dunia sebagai ladang untuk menanam, sementara akhirat adalah tempat untuk menuainya. Kehidupan akhirat seseorang ditentukan oleh kehidupan pada masa di dunianya. Mengupayakan "kesuksesan" bangsa adalah cita-cita yang mulia dan agung. Namun ketika di dunia hanya dipakai untuk ber-ipteks saja, tanpa ada keimanan dan ketaqwaan, maka habislah kehidupan akhiratnya dan tidak mendapatkan bagian surga. Di sisi lain ketika di dunia hanya dipakai untuk Imtaq saja tanpa ada Ipteks, maka bangsa yang mayoritas umat Islam ini akan terbelakang dan jatuh di dunia internasional.

Idealnya, pembelajaran yang bagus adalah Al-Qur'an, karena merupakan rajanya ilmu. Hanya saja, mengajak ke Surga itu butuh strategi, sehingga perlu memasukkan mata pelajaran umum yang diujikan secara nasional, hal ini karena terpaksa dan amal shalehnya peserta didik, sebab orang awam itu dalam memilih pemimpin melihat kualitas akademiknya/ ijazah tertinggi, tetapi pelajaran umum bisa diimtakkan dengan harapan menghantarkan peserta didik sukses primaganda (dunia akhirat), walau pada kenyataannya, Tuhan mengangkat derajat manusia bagi siapa yang Dia kehendaki sebagaimana nilai pendidikan QS. Yasin: 82, namun hal ini adalah wujud amal baik seluruh manusia yang mempunyai kewajiban menuntut ilmu sampai kapanpun, lebih-lebih sampai jenjang tertinggi. Di samping itu, semua pendidik harus memberikan bekal pada peserta didik untuk mengatasi konflik kehidupan dengan kendali konflik melalui dunia pendidikan dengan harapan meminimalisir tindakan negatif yang tidak sesuai dengan ajaran Islam. Konsep implementasi pembelajaran ini menekankan pada aspek materi dengan pedoman transfer of value bukan transfer of knowleage saja yang intinya pembelajaran ini menerapkan prinsip kolaborasi dan integrasi atau juga dikenal dengan istilah 2 in 1 (two in one). Kolaborasi yang dimaksudkan yaitu dengan mengamalkan nilai pendidikan yang terkandung dalam Q.S Al-'Alaq: 1 dan mengintegrasikan dengan nilai agama yang terintegrasi dengan pembahasan.

Adapun materi pembelajaran dikemas dua hal yaitu ketuhanan dan kemanusiaan, yaitu pengintegrasikan yang berhubungan dengan Tuhan (ibadah mahdhah) dan pengintegrasikan yang berhubungan dengan sesame manusia maupun 
Siti Hesniyatul Jamila

lingkungannya (ibadah ghairu mahdhah) dalam rangka mengagungkan Tuhan saja. Hal ini karena ada ketenangan batin dan janji kehidupan setelah mati, sedangkan ilmu memberi ketenangan sekaligus kemudahan bagi kehidupan di dunia. Oleh karena itu, proses integrasi bukan berarti setiap pokok dilegalkan dengan ayat-ayat al-Qur'an, melainkan bisa sekedar mengambil hikmah yang dapat diambil peserta sebagai bekal menjalani kehidupan.

Berikut ini contoh materi di buku mata pelajaran Biologi yang terintegrasi IMTAQ.

\section{Ciri-Ciri Makhluk Hidup}

Contoh Kolaborasi: "Ciri-ciri makhluk hidup antara lain adalah Allah menjadikan butuh makan dan minum serta bergerak. Maha Sayang Allah menjadikan tubuh dapat bergerak sehingga kita dapat melakukan berbagai aktivitas".

Contoh integrasi manusia dijadikan Tuhan butuh makan dan minum: "Kita agungkan Allah SWT dengan menghindari makanan dan minuman yang diharamkanNya. Yang diharamkan adalah bangkai, darah, dan daging babi. Termasuk bangkai adalah seluruh hewan yang mati tanpa disembelih atau memang hewan itu tidak memiliki aliran darah yang sempurna. Bangkai haram dikecualikan bangkai hewan yang hidup di air. Jika kita melanggar aturan Allah ini, maka diancam dengan siksa neraka yang sangat pedih."

Contoh Integrasi Manusia dijadikan Tuhan bergerak: "Kita mohon pada Tuhan agar selalu digerakkan pada kebaikan dan dicegah bergerak pada kemaksiatan. Contoh: selalu mengagungkan Allah dengan sholat, belajar, bersedekah dan ibadah yang lain. Jika kita di dunia bergerak menuju kebaikan, maka di akhirat dimasukkan ke dalam surga selama-lamanya."

Di samping itu, dalam implementasinya, selain memakai buku materi Biologi (SD/MI) 2 in 1 dalam kolaborasi dan mengintegrasikan pembelajaran, peserta didik juga dilatih mengintegrasikan materi mata pelajaran
Biologi yang mereka dipelajari dengan menggunakan dua prinsip yaitu kolaborasi dan integrasi dan selalu dibina pendidik. $\mathrm{Hal}$ ini dimaksudkan untuk melatih kemampuan berpikir dan kreatifitas peserta didik serta melatih mereka untuk selalu belajar mengagungkan Tuhan dalam belajar, sekalipun mata pelajaran umum seperti Biologi, selain juga dikarenakan belum ada buku Biologi berbasis IMTAQ yang dijadikan pedoman secara nasional. Itupun sesekali saja dalam mengimplementasikan pembelajaran terpadu ini. Melihat materi, apakah memungkinkan untuk dikolaborasi dan diintegrasikan atau tidak. Maka dari itu, hal ini diminimalizir dengan adanya buku Biologi (SD/MI) 2 in 1 yang dijadikan contoh dalam mengintegrasikan materi biologi berbasis IMTAQ pada tingkat SMP/MTs dan SMA/MA. Hal ini terbiasa dilakukan oleh pendidik yang sudah mempunyai kemampuan untuk mengintegrasikan pembelajaran terpadu.

Dalam inovasi pembelajaran yang dilakukan, pendidik juga bisa menggunakan media pembelajaran DVD Harun Yahya, misalnya salah satu contoh materi yang pernah ditonton adalah berjudul "Keajaiban Dibalik Nafas" dengan tema "Hidung, lender, dan rambut getar, tenggorokan, paruparu dan hemoglobin. Pendidik menyuruh semua peserta didik memperhatikan dan mencatat materi yang terkandung di video tersebut, kemudian pendidik menyuruh beberapa peserta didik untuk mempresentasikan ke depan kelas secara individu, baik kolaborasi maupun mengintegrasikan. Adapun salah satu hasil kolaborasi dan integrasi dari pemahaman peserta didik adalah sebagai berikut :

"Alhamdulillah Tuhan menjadikan kita hamba yang masih bernafas. Sungguh nafas adalah karunia terbesar, sebab dengan manusia masih bernafas, maka manusia masih mempunyai kesempatan di dunia ini untuk menabung amal baik sebagai bekal menuju kematian atau kehidupan di akhirat. Oleh karena itu, kita gunakan hidup ini untuk beriman atau kita gunakan tiap desah nafas kita untuk selalu 
mengagungkan Tuhan kapan saja dan dimana saja."

Tujuan dari inovasi pembelajaran ini adalah dalam rangka belajar jadi pemimpin bagi orang takwa dan tidak mati kecuali dalam keadaan iman, sebagaimana nilai pendidikan yang ada dalam Q.S AlBaqarah ayat 132 dan 39. Di samping itu, pelatihan ilmu kependidikan itu butuh pembiasaan dan keberanian diri untuk menyampaikan dan mengingatkan, serta belajar sejak dini untuk kepemimpinan merupakan kesempatan. Bunyi ayat alQur'annya adalah "waj'alnaa lil muttaqiiina imaaamaaa walaa tamuutunna illa wa antum mu'slimiiin". Peserta didik diberi pemahaman akan pentingnya pembelajaran terpadu ini, dan rata-rata mereka memahami pentingnya pembelajaran. Hal ini dibuktikan dengan antusiasme mereka dalam pembelajaran, baik ketika melatih diri dalam mengkolaborasi dan mengintegrasikan materi berbasis IMTAQ, atau ketika berpartisipasi dalam inovasi pembelajaran yang lain.

Berikut ini deskripsi pembelajaran dan contoh kolaborasi dan integrasi yang dilakukan peserta didik pada mata pelajaran Biologi soal Detik-detik UN 93 No. 27 : Adapun soal detik-detik UN membahas tentang apa yang harus dilakukan masyarakat ketika hujan untuk mencegah terjadinya banjir. Sambil menjawab soal tersebut, peserta didik juga dilatih mengkolaborasi dan mengintegrasikan materi tersebut. Berikut ini hasil pemikiran peserta didik yaitu, Contoh kolaborasi : Kita agungkan Tuhan tiap melihat peristiwa, termasuk hujan. Hujan itu terjadi atas kehendak Tuhan. Contoh integrasi : menurut peserta didik, air itu diibaratkan dengan ilmu, dan banjir diibaratkan ilmu yang tidak manfaat, sebab air banjir tidak bisa dimanfaatkan oleh manusia baik untuk minum, mandi dan sebagainya. Bahkan, banjir bisa membahayakan bagi manusia. Maka untuk mencegah terjadinya banjir, sama dengan cara mencegah ilmu tidak manfaat sebagaimana banjir yaitu dengan cara melakukan proses sebaik mungkin dalam mencari ilmu. Misalnya hormati majelis ilmu dengan tidak menganggu pembelajaran dan menghormati pendidik sebagai orang yang berilmu. Karena jika tidak demikian, maka ilmu yang diperoleh besar kemungkinan bisa tidak bermanfaat, dan jika ilmu tidak manfaat maka akan membahayakan bagi pemiliknya, sebab tidak akan diamalkan dan terancam masuk neraka.

Jika dilihat dari faktor pendidik, ada perbedaan kualitas dalam mengkolaborasi dan mengintegrasikan pembelajaran, dimungkinkan karena latar belakang pendidikan formal maupun non formal yang dialami oleh pendidik tersebut, sehingga kadangkala guru mata pelajaran Biologi sering sharing dengan guru mata pelajaran PAI yang merupakan alumni STIT AI-Unwatul Wutsqo yang pernah memperoleh mata kuliah tersebut. Jadi, jika ada materi yang memungkinkan untuk dikolaborasi dan diintegrasikan dengan IMTAQ, dan guru mata pelajaran Biologi kurang menguasai dalam menngkolaborasi dan menginterasikan materi, maka guru mata pelajaran Biologi juga sempat menerapkan pembelajaran guru ganda dengan guru PAI yang merupakan alumni STIT Al-Urwatul Wutsqo Jombang. Disinilah harapannya, mengapa di STIT Al-Urwatul Wutsqo menerapkan mata kuliah "Ipteks berbasis IMTAQ", adapun materi yang diimtakkan pada mata kuliah ini adalah materi mata pelajaran Biologi, Matematika dan Bahasa Indonesia. Mahasiswa selain dikader menjadi guru PAI murni, juga diharapkan bisa membantu guru mata pelajaran Biologi atau mata pelajaran umum yang lain untuk mengkolaborasi dan mengintegrasikan pembelajaran IMTAQ di lembaga manapun tanpa terkecuali. Inilah nilai plus dari pengembangan kurikulum yang dilakukan di lembaga pendidikan yang berada di bawah naungan yayasan Muhammad Ya'qub Jombang. Pengembangan kurikulum ini dilakukan dalam rangka mewujudkan visi misi sekolah dan 
Siti Hesniyatul Jamila

perguruan Tinggi serta mengamalkan nilai pendidikan QS. Al-Baqarah ayat 132 yang mencetak generasi pemimpin bagi orang takwa dan tidak mati kecuali dalam keadaan beriman serta QS. Al-Baqarah ayat 39 , yang merupakan seruan bagi manusia untuk mengagungkan Tuhan dengan mengajak tidak ingkar dan tidak mendustakan tanda Maha Kuasa-Nya Tuhan baik yang terbaca dan terwujud. Adapun yang terbaca adalah al-Qur'an dan yang terwujud adalah alam semesta. Adapun visi misi sekolah dan perguruan Tinggi sudah terintegrasi dengan tujuan pendidikan nasional.

Adapun dilihat dari sistem evaluasi, tidak ubahnya evaluasi pada umumnya, baik di sekolah/madrasah maupun di perguruan tinggi. Evaluasi pembelajaran dilihat dalam tiga domain yang meliputi domain kognitif, domain psikomotorik dan domain afektif, juga mengadakan pengayaan bagi peserta didik spesial, salah satu bentuk pengayaan yang dilakukan adalah dengan memberi kesempatan kepada peserta didik tersebut untuk menjadi guru privat bagi teman kelasnya, hal ini dalam rangka juga melatih kepeduliaan peserta didik kepada orang terdekat dan manusia pada umumnya, walaupun secara umum sudah dilakukan pelatihan ilmu kependidikan secara menyeluruh oleh pendidik kepada semua peserta didik. Di samping itu, manusia hanya berusaha dan Tuhanlah yang Maha Menghendaki terhadap apapun bagi hamba-Nya, baik berupa ilmu, kekuasaan dan kekayaan harta benda serta sebagainya. Oleh karena itu, pendidik tetap mengadakan remedial bagi peserta didik di bawah standar. Semoga kita selalu diberi keikhlasan dalam beramal, hanya dengan keikhlasan berarti manusia tersebut dimampukan Tuhan beramal baik, sebab jika tidak ada keikhlasan dalam diri, berarti manusia tersebut belum beramal baik, malah justru ia beramal yang dikhawatirkan menjadi penyebab masuk neraka yang sangat pedih, jika tidak ada kemauan untuk bertaubat serta selalu berusaha mencari petunjuk Tuhan.
Berdasarkan uraian diatas, maka disimpulkan bahwa implementasi model pembelajaran terpadu pada mata pelajaran Biologi di lembaga yang berada di bawah naungan yayasan Muhammad Ya'qub disebut dengan Model Shared (model terbagi). Model Shared (model terbagi) merupakan bentuk pemaduan pembelajaran akibat adanya overlapping konsep atau ide pada dua mata pelajaran sehingga menuntun peserta didik untuk membuka wawasan dan cara berpikir yang luas dan mendalam melalui pemahaman terhadap konsep secara lintas disiplin ilmu, atau suatu model pembelajaran terpadu dimana pengembangan disiplin ilmu yang memayungi kurikulum silang. Namun, implementasi model pembelajaran terpadu pada mata pelajaran Biologi di lembaga yang berada di bawah naungan yayasan Muhammad Ya'qub lebih unggul karena terdapat inovasi pembelajaran yang dilakukan yaitu selain menuntun peserta didik untuk membuka wawasan dan cara berpikir yang luas dan mendalam melalui pemahaman terhadap konsep secara lintas disiplin ilmu, pendidik juga membekali peserta didik dengan ilmu kependidikan dengan harapan peserta didik juga memiliki kemauan yang tinggi untuk menjadi pemimpin bagi orang yang takwa sebagaimana nilai pendidikan yang terdapat pada Q.S AI-Baqarah: 132.

\section{Analisis Data}

Implementasi model pembelajaran terpadu di lembaga pendidikan yang berada di bawah naungan yayasan Muhammad Ya'qub Jombang merupakan aplikasi pengembangan kurikulum yang diibaratkan dengan dua sayap, yaitu sayap kanan adalah al-Qur'an yang merupakan rajanya ilmu (mulai dari hafalan, terjemah, analisa shorof nahwu di al-Qur'an, baca kitab, keguruan al-Qur'an, dan belajar cara mengamalkan al-Qur'an) dan sayap kiri adalah pelajaran yang diujikan secara nasional dengan strategi mengintegrasikan pembelajaran umum dengan IMTAQ dan dibina sejak kelas satu. Adapun ciri 
menonjol pendidikan Sains di Indonesia untuk membedakan dengan pendidikan Sains di Amerika Serikat yaitu adanya nilainilai agama yang masuk ke dalam kurikulum. Melalui pendidikan Sains kita mendorong anak didik untuk dapat meningkatkan iman dan takwanya kepada Tuhan yang Maha Esa, pencipta alam dan seisinya. Selain itu, hal ini dalam rangka menjadi warga negara yang ideal (beriman dan bertakwa pada tanda Maha Kuasa-Nya Allah), karena kekokohan sejarah peradaban ditentukan oleh tinggi rendahnya akhlak manusia sebagaimana nilai pendidikan Q.S. Al-'A'raf : 96. Di samping itu, arah umum pelaksanaan pendidikan adalah upaya memanusiakan manusia atau membantu proses humanisasi. Artinya, pelaksanakan dan proses pendidikan harus mampu membantu peserta didik agar menjadi manusia yang berbudaya tinggi dan bernilai tinggi (bermoral, berwatak, bertanggung jawab dan bersosialitas).

Pendidikan butuh pergaulan, dan pembelajaran disitulah pergaulan. Jadi, pembelajaran adalah alat kependidikan. Berdasarkan hal tersebut, pendidikan tidak bisa dilepaskan dari komponen pembelajaran yang meliputi pendidik, peserta didik, materi, metode, strategi pembelajaran dan sarana penunjang, serta tercapainya tujuan. Adapun dilihat dari pencapaian tujuan, Visi Misi lembaga pendidikan yang berada di bawah naungan yayasan Muhammad Ya'qub Jombang adalah "Terwujudnya masyarakat yang berkepribadian mulia, paham Al-Qur'an dan pengagung Tuhan Maha Pencipta". Visi Misi ini sudah terintegrasi dengan UndangUndang Republik Indonesia tentang Sistem Pendidikan Nasional Nomor 20 Tahun 2003 pada BAB II tentang Dasar, Fungsi dan Tujuan yang tertera pada Pasal 3, Pendidikan Nasional berfungsi mengembangkan kemampuan dan membentuk watak serta peradaban bangsa yang bermartabat dalam rangka mencerdaskan kehidupan bangsa, bertujuan untuk berkembangnya potensi peserta didik agar menjadi manusia yang beriman dan bertakwa kepada Tuhan Yang Maha Esa, berakhlak mulia, sehat, berilmu, cakap, kreatif, mandiri, dan menjadi warga negara yang demokratis serta bertanggung jawab. Selain itu, UNESCO memberikan arahan bahwa secara global pendidikan harus mengarah untuk mengembangkan potensi individu dengan berprinsip pada learning to know, learning to do, learning to be, dan learning to live together.

Strategi pembelajaran terpadu ini yaitu dengan mengkolaborasi dan mengintegrasikan Imtaq pada mata pelajaran Biologi. Dimaksudkan kolaborasi adalah mengamalkan nilai pendidikan Q.S. Al-'Alaq: 1 dalam setiap membaca peristiwa yang ada, sedangkan integrasi adalah memadukan Imtaq atau PAI baik dari segi Fiqih, Aqidah Akhlak maupun SKI dengan materi pembahasan Biologi. Selain itu, Al-Attas dan Al-Golshani menilai bahwa Sains tidak bisa dipisahkan dari agama dan filsafat. Al-Attas dan Al-Golshani menghubungkan Sains dan agama secara integratif. Hal ini merupakan bagian dari kecenderungan baru dalam Sains (The new story of science). Di samping itu, dilihat dari metode pembelajaran, ada beberapa metode yang mencerminkan ciri khas Imtaq yaitu metode Value Clarification Technique (VCT) atau pengungkapan nilai, Moralizing (menasehati), serba membiarkan (a laisseafaire attitude) yang mana metodemetode ini merupakan nilai plus daripada pembelajaran yang diimplementasikan.

Dilihat dari sarana prasarana, dalam pembelajarannya, selain menggunakan buku detik-detik UN sejak kelas satu buku saku Biologi dan Biologi (SD/MI) 2 in 1, juga menggunakan media pembelajaran DVD Harun Yahya, mengingat belum ada buku Biologi yang berbasis IMTAQ yang digunakan secara nasional. Pembelajaran terpadu ini memiliki karakteristik yaitu holistik, bermakna, otentik dan aktif. Hal ini sesuai dengan prinsip-prinsip kunci tarbiyah yaitu fitrah, unik, holistik, integratif, bertahap, mempertimbangkan emosi, pola dan pencarian makna, problem solving, pengetahuan mendalam, pengayaan, hand 
Siti Hesniyatul Jamila

on/aktif, realistik dan relevan, berorientasi pada nilai, berorientasi sosial, pembelajaran dengan model (modelling).

Adapun materi pembelajaran dikemas dua hal: (1) Ketuhanan, (2) Kemanusiaan, yaitu pengintegrasian yang berhubungan dengan Allah (ibadah mahdhah) dan pengintegrasian yang berhubungan dengan sesama manusia maupun lingkungannya (ibadah ghairu mahdhah) dalam rangka berhubungan dengan Allah saja. Hal ini karena agama memberikan ketenangan batin dan ada janji kehidupan setelah mati, sedangkan ilmu memberi ketenangan dan sekaligus kemudahan bagi kehidupan di dunia. Oleh karena itu, proses integrasi bukan berarti setiap pokok bahasan harus dilegalkan dengan ayat-ayat Al-Qur'an, melainkan dengan setiap pokok bahasan tersebut diambil hikmah yang dapat diambil peserta didik bagi kehidupannya (nilai spiritual).

Dilihat dari faktor pendidik, terdapat perbedaan kemampuan dalam mengkolaborasi dan mengintegrasikan pembelajaran. Kualitas dalam hal ini adalah bagaimana pendidik menjalankan tugas dengan baik yaitu mendidik dan menentukan masa depan peserta didik dengan pembelajaran yang transfer of value bukan transfer of knowleage saja, karena idealnya mendidik atau transfer of value adalah tugas semua civitas yang berkecimpung di dunia pendidikan terutama pendidik, karena suksesnya pendidikan tergantung pada suksesnya pembelajaran. Adapun Evaluasi pembelajaran terpadu ini hampir sama dengan evaluasi pada umumnya yaitu lebih menekankan pada suksesnya tiga domain penilaian menurut Bloom, yaitu aspek kognitif, afektif dan psikomotorik, juga pengayaan bagi peserta didik spesial dan remedial bagi peserta didik di bawah standar.

Berdasarkan uraian diatas, maka disimpulkan bahwa pembelajaran terpadu pada mata pelajaran Biologi disebut Model Shared (model terbagi). Model Shared (model terbagi) merupakan bentuk pemaduan pembelajaran akibat adanya overlapping konsep atau ide pada dua mata pelajaran sehingga menuntun peserta didik untuk membuka wawasan dan cara berpikir yang luas dan mendalam melalui pemahaman terhadap konsep secara lintas disiplin ilmu, atau suatu model pembelajaran terpadu dimana pengembangan disiplin ilmu yang memayungi kurikulum silang. Namun, model pembelajaran terpadu yang diimplementasikan di lembaga-lembaga yang berada di bawah naungan yayasan Muhammad Ya'qub Jombang lebih unggul karena terdapat inovasi pembelajaran yang dilakukan yaitu pendidik juga membekali peserta didik dengan ilmu kependidikan dengan harapan peserta didik juga memiliki kemauan yang tinggi untuk menjadi pemimpin bagi orang yang takwa sebagaimana nilai pendidikan yang terdapat dalam Q.S AI-Baqarah: 132.

\section{Kesimpulan}

Pembelajaran terpadu pada mata pelajaran Biologi disebut dengan model Shared (model terbagi). Namun, Pembelajaran terpadu di lembaga pendidikan yang berada di bawah naungan yayasan Muhammad Ya'qub Jombang lebih unggul karena juga ada pelatihan ilmu kependidikan dalam pembelajaran. Tujuan pembelajaran yaitu terwujudnya Visi Misi yang sudah terintegrasi dengan tujuan Pendidikan Nasional serta nilai pendidikan yang terkandung dalam QS. Al-Baqarah : 132 dan 39. Dilihat dari faktor pendidik pembelajaran yaitu masih terdapat perbedaan kualitas dalam mengkolaborasi dan mengintegrasikan pembelajaran. Dilihat dari faktor peserta didik yaitu sudah memahami pentingnya pembelajaran. Sarana prasarana pembelajaran ini yaitu Buku Detik-Detik Ujian Nasional, buku saku Biologi, media pembelajaran DVD Harun Yahya dan buku Sains (SD/MI) 2 In 1. Strategi Pembelajaran yaitu kolaborasi dan integrasi, kolaborasi yang dimaksudkan yaitu dengan mengamalkan nilai pendidikan yang terkandung dalam Q.S AI- 
'Alaq: 1 dan mengintegrasikan dengan nilai agama yang terintegrasi dengan pembahasan. Dilihat dari faktor materi pembelajaran, dibagi dua kelompok besar yaitu ketuhanan dan kemanusiaan. Sistem evaluasi/penilaian: Suksesnya pembelajaran dilihat pada suksesnya domain kognitif, afektif dan Psikomotorik, juga pengayaan bagi peserta didik spesial dan remedial bagi peserta didik di bawah standar. Saran: Implementasi model pembelajaran terpadu di lembaga pendidikan yang berada di bawah naungan yayasan Muhammad Ya'qub Jombang untuk sementara sudah banyak mengandung nilai positif. Oleh karena itu, ada baiknya lebih disempurnakan dan dijadikan pertimbangan untuk diimplementasikan melalui kebijakan secara nasional.

\section{DAFTAR PUSTAKA}

Abduh, M. 2008. Metode Pendidikan Qur'ani. Jakarta: Kemenag RI.

Abidin, Zaenal. 2010. Konsep Model Pembelajaran Dalam perspektif alQur'an. Banjarmasin: Pascasarjana IAIN Antasari.

Barizi, Ahmad. 2011. Pendidikan Integratif Akar Tradisi dan Integrasi Keilmuan Pendidikan Islam. Malang: UIN Maliki Press.

Meyer. 2010. Mendesain Model Pembelajaran Inovatif-Progressif. Jakarta: Kencana Prenada Media Group.

Naim, Ngainun. 2010. Rekonstruksi Pendidikan Nasional. Yogyakarta: Teras.

Nata, Abuddin. 2011. Pemikiran Pendidikan Islam \& Barat. Jakarta: Raja Grafindo Persada.

Ramayulis. 2013. IImu Pendidikan Islam. Jakarta: Kalam Mulia.

Suardi, Moh. 2012. Pengantar Pendidikan Teori dan Aplikasi. Jakarta: Indeks.

Trianto. 2009. Mendesain Model Pembelajaran Inovatif Progresif. Jakarta: Kencana.

Trianto. 2010. Model Pembelajaran Terpadu. Surabaya: Bumi Aksara.

Wiyani, Novan Ardi. 2012. Pendidikan Karakter Berbasis Iman dan Taqwa. Yogyakarta: Teras.

Zainuddin, M. 2010. Paradigma Pendidikan Terpadu. Malang: UIN Malang Press. 